\title{
Padre José Maurício Nunes Garcia e os "inventores do Brasil": a perspectiva sobre o negro dos anos 1930 e o nacionalismo em Arte
}

\author{
Pedro Razzante Vaccari \\ Universidade Estadual Paulista | Orcid: 0000-0002-2492-9362
}

\begin{abstract}
Resumo
A visão que começou a ser esboçada na década de 1930, aquela concernente à formação dos conceitos de Nação e Pátria que foram impulsionados pela Era Vargas, imprescindíveis para a estruturação do país enquanto polo industrial da América Latina, veio embasada por revisionistas, que se tornaram conhecidos, posteriormente, como os "inventores do Brasil". Delinearam um modo de pensar o Nacionalismo, reescreveram a História do Brasil sob uma nova perspectiva, estudos sobre a formaçáo racial, cultural e social do país. Este artigo visa a trazer à tona aspectos sociais e antropológicos que tangenciam a biografia e obra do Padre José Maurício Nunes Garcia. Para o delineamento de um passado glorioso, se elegeram algumas figuras importantes para a construçáo da História Música no Brasil, e para isso utilizaram, como símbolo da Música Colonial, o Padre José Maurício. No entanto, teria sido proposital o 'embranquecimento' histórico pelo qual ele passou?
\end{abstract}

Palavras-chave: Padre José Maurício; inventores do Brasil; perspectiva dos anos 1930; nacionalismo.

\section{Father José Maurício Nunes Garcia and the "Brazil's Inventors":}

A Perspective about the Negro in the 1930s and the Nationalism in Art

\section{Abstract}

The perspective that began to be drawn in the 1930s, concerning the conceptual construction of the nation and country, built during the Vargas Era, fundamental for Brazil as Latin America industrial leader, was embased by revisionists, that became known as "Brazil Inventors". They have designed a way of thinking the Nationalism, and wrote the Brazil's History from a new survey, with studies concerning race, culture and society of the country. This paper proposes to bring up social and anthropological aspects that shaped the biography and work of Father José Maurício Nunes Garcia. For structuring a glorious Past, it was elected some important figures of the Brazil's History of Music. For that it was used as the Colonial Music Symbol the Father José Maurício. However, was it purposeful his historical whitening?

Keywords: Father José Maurício; Brazil’s inventors; 1930s Perspective; Nationalism.

\section{El Padre José Maurício Nunes Garcia y los “inventores del Brasil”: una perspectiva sobre el negro de los ańos 1930 y el Nacionalismo en el Arte.}

\section{Resumen}

La visión que comenzó a ser esbozada en la década de 1930, aquella que concierne a la formación de los conceptos de Nación y Patria, impulsionados en la era de Vargas, son imprescindibles para la extructuración del pais como polo industrial de América Latina y vino embasada por revisionistas que, posteriormente, fueron conocidos como los “inventores del Brasil." Delinearon un modo de pensar el Nacionalismo, e reescribieron la Historia del Brasil desde una nueva perspectiva con estúdios sobre la formación racial, cultural y social del país. Este artículo se propone traer a la luz aspectos sociales y antropológicos que perpasan la biografia y la obra del Padre José Maurício Nunes Garcia. Para delinear un pasado glorioso, eligieron algunas figuras importantes de la formación de la Historia de la Música en Brasil. Para tal utilizaron como símbolo de la Música Colonial al Padre José Maurício. Sin embargo, habria sido proposital el 'blanqueamiento' histórico por el que pasó?

Palavras-chave: Padre José Maurício; inventores del Brasil; perspectiva de los años 1930; nacionalismo. 


\section{¿ntroduçáo}

A análise sobre a perspectiva histórica apresentada durante a Era Vargas (19301945), a partir do debruçar sobre as obras capitais dos chamados "Inventores do Brasil" (FARINACCIO, 2001), pôde propiciar uma visão de um panorama em que se aprofundaram as noçóes de "Nacionalismo". E o porquê, no ideal nacionalista dos anos 1930, forjou-se a necessidade de estruturaçâo e eleição de símbolos nacionais representativos de uma "brasilidade" - sendo o próprio Heitor Villa-Lobos e o modernista Mário de Andrade alguns desses símbolos. Para a estruturaçáo de um passado fulgurante e majestoso, os musicólogos elencaram algumas personalidades importantes para a construção da Música de Concerto no país, apontando, como representante da Música Colonial, o Padre José Maurício Nunes Garcia, e da Música Imperial, Antônio Carlos Gomes. Entretanto parece bastante visível o 'embranquecimento' histórico porque passaram essas figuras afrodescendentes, processo que se tornou ainda mais evidente durante o auge do Nacionalismo, a partir da Semana de Arte Moderna de 1922.

O olhar sobre a História depende, sobremaneira, daquele que a vivencia e a escreve. Quiçá fosse indesejável, ainda que inconscientemente, que grandes nomes artísticos brasileiros fossem associados à negritude. Estudos relativamente recentes, como Uma história de branqueamento ou o negro em questão (HOFBAUER, 2006) - que mostra como a importaçáo de mão de obra europeia caucasiana atendia não à demanda por trabalho mas sim a um deliberado branqueamento social, e $A$ reaçâo do cético à violência: o caso Machado de Assis (KRAUSE, 2008) - em que o autor argumenta como um efetivo clareamento de Machado de Assis serviu como uma pretensa afirmaçáo de sua genialidade, ilustram como houve uma tentativa de embranquecer as figuras negras relevantes da cultura brasileira. No artigo O Padre José Maurício Nunes Garcia e o Mulatismo Musical: embranquecimento histórico? (VACCARI, 2018), desenvolve-se a tese de que o tímido e às vezes explícito embranquecimento de José Maurício Nunes Garcia por meio de retratos, em que os traços negros são nitidamente branqueados - cabelos alisados e nariz afilado, e a própria tez clareada - e pela própria Historiografia da Música Brasileira, se não foi intencional deixou sequelas históricas e culturais profundas.

A minha crítica aqui vai de encontro, especificamente, aos teóricos do Nacionalismo brasileiro que, embora realmente bem-intencionados, ainda estavam influenciados pelas Teorias Raciais dos séculos XIX e XX - vide Lilia SCHWARCZ (1993). O objetivo é apontar que havia uma preocupação de profundidade antropológica na fala de Gilberto Freyre - que já se sobrepóe ao discurso eugenista do médico Nina Rodrigues (1862-1906), em que este dissertava haver culturas e etnias superiores e outras inferiores. Esse discurso notadamente racista foi revisto por Freyre de forma a adotar uma postura antagônica, porém mesmo em Casa Grande e Senzala (com 1 $1^{\text {a }}$ edição de 1933) e Sobrados e mucambos (com $1^{\text {a }}$ edição de 1936) o autor por vezes finda por reincidir na visão discriminatória cientificista - conforme veremos ao longo deste texto. A principal tese de Freyre - a de que haveria uma democracia racial reinando no Brasil, plenamente amalgamada, sem conflitos étnicos e desejada pelo próprio colonizador lusitano - logo é desmontada por antropólogos seguintes, principalmente Arthur Ramos em As culturas negras no Novo Mundo (com 1a edição de 1935). Sem citar nomes, ele coloca: "O estudo científico do negro deve fugir a todo sociologismo romântico, que compromete a visão real dos seus problemas". (RAMOS, 1979, p. 21). 
O pioneiro a romper com esse paradigma da democracia racial efetivamente foi o sociólogo Florestan Fernandes. Em sua obra O negro no mundo dos brancos argumenta:

Se os brancos, negros e mestiços podem conviver de "forma democrática" no Brasil, por que o mesmo processo seria impossível em outras regióes? Não obstante, o que é uma democracia racial? A ausência de tensões abertas e de conflitos permanentes é, em si mesma, índice de "boa" organização das relaçóes sociais? (FERNANDES, 2006, p. 39).

O fato é que há evidências de que a tensão social entre negros e brancos nunca foi superada. $\mathrm{O}$ alto índice de genocídio negro no segundo país com maior população negra do mundo - estando atrás apenas da Nigéria - denota que a utopia freyriana não só é absolutamente imaginada, como a tal democracia racial é apenas um termo cunhado entre intelectuais que visavam a um gradativo porém contínuo embranquecimento populacional. Conforme argumenta Abdias Nascimento:

Freyre cunha eufemismos raciais tendo em vista racionalizar as relações de raça no país, como exemplifica sua ênfase no termo morenidade, não se trata de ingênuo jogo de palavras, mas sim de proposta vazando uma extremamente perigosa mística racista, cujo objetivo é o desaparecimento inapelável do descendente africano, tanto fisicamente, quanto espiritualmente, através do malicioso processo do embranquecer a pele negra e a cultura do negro. (NASCIMENTO, 2016, p. 22-23).

O que essa afirmação vem atestar é que o processo de embranquecimento tomou todos os meios da sociedade brasileira - não apenas a construção física de um idealizado homem branco puro nos trópicos, todavia também no plano psicológico, cultural e artístico. A perpetuação do pensamento de que para ascender socialmente é necessário ser branco ou, pelo menos, parecer ser branco, atravessou mais de um século após a Abolição da Escravidão, passando incólume ao revisionismo histórico cristalizado, em grande parte, no Nacionalismo dos anos 1930. Esse revisionismo buscava tornar brancas, ou quase brancas, figuras reconhecidamente negras, como o poeta Castro Alves, o escritor Machado de Assis, e até mesmo o modernista afrodescendente, Mário de Andrade. Nas palavras do antropólogo negro Kabengele Munanga: "Apesar de o processo de branqueamento físico da sociedade ter fracassado, seu ideal inculcado através de mecanismos psicológicos ficou intacto no inconsciente coletivo brasileiro”. (MUNANGA, 2019, p. 23).

Dentro do macrocosmo da História do Brasil, há de se ressaltar a importância de que aqui se estruturaram diversos microcosmos culturais - da mesma forma que se delinearam as raças, as distintas variaçóes socioculturais se acomodaram, irregularmente, no vasto âmbito da conformidade brasílica. Longe de corroborar a visão determinista freyriana (FREYRE, 2016), onde as três raças - negro, branco e índio - conviveriam harmoniosamente, o fato é que não há como analisar suas idiossincrasias de maneira separada e reducionista. Antes deve-se olhar sob o prisma transcultural, onde o Brasil assumiu, a partir da consubstanciação das raças, o tipo brasileiro por excelência, nem negro, nem caucasiano e nem ameríndio, mas a junção das três - conforme o antropólogo Darcy Ribeiro (2015).

À parte esse desejo de alguns antropólogos de unificarem o brasileiro em um único modelo racial, há de se convir que as raças amalgamadas conservaram, por meio dos séculos, características que as etnias carregaram como traços culturais arraigados. $\mathrm{O}$ negro trouxe, atrelado à sua história, o estigma da escravidão - e é impossível tratar dessa etnia sem analisar os aspectos socioculturais que, inevitavelmente, ela recebeu do regime escravocrata. 
Entrementes esse ideário, amplamente reforçado por Gilberto Freyre (2016; 1977), não leva em conta a aculturação e a miscigenação que resultaram do contato do negro com as outras raças - a sua separação de seus ramos culturais - menciona o antropólogo Arthur Ramos. Dessa forma, não apenas o ser escravo delineou o ser negro no Brasil, como as condições locais sui generis de sincretismo cultural - fenômeno que quase não existiu ou teve menor impacto em sociedades como a norte-americana.

Essa perspectiva foi endossada pelos chamados "Inventores do Brasil", teóricos e historiadores que visavam ao revisionismo histórico, onde uma nova nação seria fundada, despontando como uma unidade territorial, econômica e cultural, que poderia dar impulso ao progresso industrial incipiente da Era Vargas. Dentre esses teóricos destacaram-se, principalmente, Gilberto Freyre, Sérgio Buarque de Holanda e, no Modernismo, Mário de Andrade. Todos tentaram, de certa maneira, reconstruir o país sob sua perspectiva - perspectiva da época, obviamente, calcada pelo Nacionalismo e por muitos equívocos antropológicos.

Um dos pioneiros a tratar a História sob o prisma da formação de um sentido de Nação foi Sérgio Buarque de Holanda (1902-1982). Segundo ele, a nação brasileira teria sofrido, desde sua colonização, de estrangeirismos e demandas próprias de outra cultura, outra sociedade, outra delineação populacional, temperamento climático e hábitos e costumes. Terra continental de tamanho geográfico até então desconhecida dos portugueses, conheceu uma subjugação e espoliação talvez deveras desregrada - exploração preguiçosa, sem considerar processos sistemáticos de cultivo e desenvolvimento agrário e cultural. Essa colonização cega não levou em conta a proporção enorme de terra, seus domínios específicos de língua, sociedade e cultura que aqui habitavam. (HOLANDA, 2016)

Além de Buarque de Holanda, não há como falar de Modernismo e Nacionalismo sem mencionar Mário de Andrade (1893-1945). Para ele, o fato de o país ter se delineado antes que a raça, tornou o Brasil conflitante no quesito de conjugação racial e apropriações culturais. (ANDRADE, 2006b, p. 11) Quem levou a ideia de indecisão e hibridez dos trópicos à pesquisa sistemática foi Gilberto Freyre (1900-1987). Para ele a consumação da própria raça brasileira - na sua acepção de "democracia racial" - deu-se de uma peculiar indefinição de povo híbrido que não seria nem africano nem europeu, mas tendo que se equilibrar entre as características às vezes díspares de ambos. Em suas palavras:
Híbrida desde o início, a sociedade brasileira é de todas da América a que se constituiu mais harmoniosamente quanto às relaçôes de raça: dentro de um ambiente de quase reciprocidade cultural que resultou no máximo de apro- veitamento dos valores e experiências dos povos atrasados pelo adiantado; no máximo de contemporizaçẫo da cultura adventícia com a nativa. (FREYRE, 2016, p. 160)

O que esses autores olvidaram, no entanto, foi que a própria imagem do índio desleixado e do negro preguiçoso constituem estereótipos calcados a partir do olhar do ibérico. Convencionou-se adotar essa postura equivocada de que quem não é branco no Brasil é procrastinador e ocioso, em contraste com o descendente de europeu - que seria trabalhador e sistemático. Esse prisma eurocêntrico que aparece em grande parte dos escritos de História e Antropologia até meados do século XX foi aos poucos sendo desmistificado e questionado. Perceba como na citação acima Freyre promulga a questão da "democracia racial": sociedade, para ele, sem conflitos étnicos e sub-classificada em povos atrasados e adiantados.

Deve-se salientar, entretanto, que aos portugueses do século XVI que aqui se instalaram não parecia interessar tanto a problemática étnica - antes travavam uma espécie de 
cruzada contra os "bárbaros hereges", fossem eles brancos, vermelhos, negros ou amarelos. Obviamente trata-se da visão freyriana muitas vezes equivocada de que o português não tinha preconceito étnico - basta lembrar a descrição pormenorizada que Michel Foucault traça da obra Las Meninas, de Diego Velázquez: os diferentes pontos de vista, seja do espectador, do pintor, ou das figuras representadas formam uma anteposição de perspectivas onde a "verdade" seria apenas parcialmente representada - ou que a possível "verdade" única sequer exista (FOUCAULT, 1970).

Para Gilberto Freyre, pouco importava se adentrassem o país indivíduos de todas as espécies e proveniências, desde que se mantivessem no Cristianismo e, preferencialmente, na Igreja Católica. Para Freyre, o português fora seduzido pela mulher indígena brasileira e pela escrava africana, e aparentemente não evitava nem tachava o contato sexual com elas - mas antes o buscava com afoito desejo; o que o preocupava , e aos padres jesuítas, era o declarado discurso herege e a falta de fé. (FREYRE, 2016) Isso denota, mais uma vez, a deliberada escrita de Freyre de modo a favorecer a miscigenação em prol de uma racialidade indistinta e vindoura.

É de causar espanto, por exemplo, que a obra $O$ mulato, de Aluísio Azevedo (18571913), publicada em 1881, embora situada no Século XIX, trate de forma tão explícita o preconceito racial no Maranhão, a ponto de o personagem principal - o "mulato" de olhos azuis Raimundo - ser ignominiosamente assassinado ao final da trama. O contexto social é basicamente o do português inserido no Nordeste, em que a visita de um sobrinho, filho de uma escrava, traz todo um burburinho que alicerçará o desfecho do drama - a morte do mulato. Considerado o marco inicial do Naturalismo em Literatura no Brasil, no entanto traz ainda alguns laivos romanescos: personagens unidimensionais, a mulher idealizada; o "mulato" é alto, formoso, de olhos azuis, educado e letrado na Europa, janota com ares de fidalgo, sem nódoas no caráter nem no bolso. (AZEVEDO, 2013, p. 35)

A supostamente intolerante religiáo católica portuguesa nâo afetaria o negro da perspectiva sócio-histórica - o africano seria, radicalmente, em sua essência religioso e devotado a divindades e, quando trazido escravizado para a América, primordialmente teísta cristão e ascético. (JUNG, 2012) Logo firmou-se uma tradição que, nos engenhos de canade-açúcar do Nordeste, os escravizados, com a permissão de seus proprietários, refizessem os procedimentos ritualísticos de suas pátrias originárias, reconstituindo os personagens e suas indumentárias, os reis e os deuses de Aruanda.

E se a música do Brasil em primeiro lugar significou uma aparente conciliação entre párocos e índios catequizados - sem considerar-se a dizimação sofrida por estes - ela seria absolutamente africana no seu conteúdo. A alardeada sensualidade imputada ao negro se manifestaria naquele que é tido como o primeiro tipo de composição musical brasileira, a modinha, amplamente disseminada pelo "mulato" (negro?) Domingos Caldas Barbosa (1739-1800). (HOLANDA, 2016) Posso argumentar que ela seria, destarte, em suas origens mais primárias, lusitana majoritariamente, nativa indígena em menor quantidade e extremamente africana.

No que tange o português, cabe lembrar, grandemente jesuítica e asceta, compondo-se, desse modo, uma consubstanciada síntese entre o escravo negro africano e o pároco católico lusitano - fusão até então impensável, mesmo no mais fantasioso romance do século XIX. Se a música brasileira seria ameríndia e portuguesa em seus princípios, ela seria majoritariamente negra, nos seus conteúdos e mesmo nas formas, do que especificamente proveniente de indígenas. 
Na ternura, na mímica excessiva, no catolicismo em que se deliciam nossos sentidos, na música, no andar, na fala, no canto de ninar menino pequeno, em tudo que é expressão sincera de vida, trazemos quase todos a marca da influência negra. (FREYRE, 2016, p. 367)

Domingos Caldas Barbosa foi o expoente máximo da música brasileira colonial do Século XVIII de um modo cultural que se faria próprio por muitos séculos na cultura do Brasil - a miscigenaçáo de elementos culturais de duas classes sociais diferentes e, mais do que isso, de raças distintas. A partir dessa mistura consolidou-se a modinha como fenômeno raro de disseminação de uma cultura elitista no seio do povo, constituindo-se uma estirpe de mistura em que características culturais diferentes coabitam a mesma estrutura, o que se traduz como um processo sociológico conhecido como aculturação. (Lakatos, 1981, p. 133) Essa aculturação não se formou somente com fatores socioculturais, todavia também foi caracterizado por um forte estigma racial - assim que a modinha fora aprofundando seus meios de afluência africana trazia consigo o preconceito voltados à comunidade negra, inclusive escravos alforriados, filhos e netos de escravos e mestiçados, e mesmo aqueles genotipicamente identificados como brancos. Não apenas a modinha carregou o estigma racial, porém o próprio instrumento que firmara a sua atuação como essencialmente "modinheiro", o violão.

Voltando às modinhas de engenho do Brasil - resultado do erotismo patriar-
cal: chamegos com negras, mulatas, primas - recordaremos que elas fizeram
furor nos salóes portugueses do século XVIII alternando com as novenas, os
lausperenes e as festas de igreja. William Beckford, que teve ocasião de ouvi-las
em casa fidalga, freqüentada também pelo arcebispo do Algarve, D. José Maria
de Melo - grande apreciador de modinhas cantadas ao violão - procurou
interpretar-lhes o encanto viscoso.(FREYRE, 2016, p. 427).

O mesmo instrumento difusor de modinhas, o violáo, seria estigmatizado como impróprio e impuro, quiçá pela familiaridade popular que ostentara. Causa certamente consternação sabermos que José Maurício, padre negro subjugado ao sistema católico ibérico, tenha inflado a capacidade corajosa de compor nesse gênero absolutamente profano, do qual restaram à posteridade apenas alguns espécimes: "Beijo a mão que me condena", "No momento da partida", "Marília si me não amas - não me diga a verdade" e a recémdescoberta "Estas lágrimas sentidas". Entrementes, é uma canção totalmente do estilo mauriciano - visto que o compositor principiara na música tangendo viola de arame e o gênero modinha tenha se formado de práticas de cordas, como a viola de arame e o próprio violáo. Posicionando-se ao lado dos mouros, argumenta Freyre (2016), teriam sido os integrantes da igreja católica os que mais teriam resistido e feito frente ampla ao domínio econômico judaico - pelo seu modo organizacional, administração efetivamente profícua e abundante à fertilidade de alimentos.

Outra característica alça o negro a um papel preponderante na história da sociedade brasileira: sua espécie civilizatória, transplantada da África, desenvolvido em amplo sedentarismo, em oposição ao nômade indígena. (FREYRE, 2016)

$\mathrm{O}$ aparentemente alto grau evolutivo civilizatório negro propiciou esse papel preponderante, assim como a sua relação com o colonizador português. No entanto, parece um preconceito a afirmação de Freyre de elencar as culturas africanas, indígenas e brancas - partindo de premissas hierárquicas anacrônicas sobrepujadas por estudos contemporâneos, como de MUNANGA (2019). 
Amplamente disseminada, essa conceituação fortaleceu-se na Europa Ocidental a partir de meados do século XIX, sendo constantemente reiterada por geraçôes de cientistas sociais e antropólogos em grande parte ainda do século XX. O cientista social francês Paul Descamps (1872-1946), por exemplo, do Instituto Internacional de Sociologia, em sua obra mais conhecida - Estado social dos povos selvagens, de 1930, em que embora afirme refutar a teoria do evolucionismo, separa os povos de acordo com categorias estereotipadas de evolução cultural: "A inferioridade técnica (de alguns povos) é unicamente devido a uma inferioridade de inteligência", ${ }^{1}$ e estigmatiza os povos a que denomina "primitivos" como dotados de "bestialidade primitiva" (DESCAMPS, 1930, p. 9).

Essa classificaçáo de povos desenvolvidos e subdesenvolvidos de acordo com a inteligência e habilidades inatas ganhou o campo biológico ao se considerarem o crânio de negros, por exemplo, como desavantajados. Conforme relata o musicólogo Manuel Araújo de Porto Alegre sobre um suposto médico, dr. Dannessy, que teria apalpado diversos crânios de afro-brasileiros, e que possuía uma cópia da máscara mortuária de José Maurício Nunes Garcia em Paris - o que teria levado à conclusão, equivocada ao olhar de Porto Alegre, de inferioridade intelectual. (PORTO ALEGRE, 1856, p. 7)

\section{Silvio Romero e a perspectiva eugênica no Brasil: as teorias raciais}

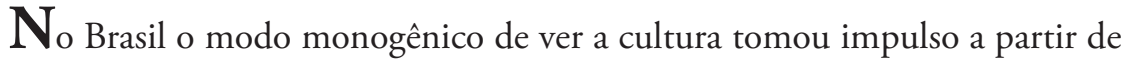
nomes como os de Silvio Romero, conforme já demonstrei anteriormente. Em sua obra A philosophia no Brasil: ensaio crítico, de 1878, começa a introduçáo remetendo a uma pureza entáo almejada: "devemos tomar novas forças em busca de um ar mais puro" (ROMERO, 1878, p. 7). Em seguida, ao declarar que havia, segundo ele, uma franca vacuidade no campo das ciências brasileiras, enumera algumas obras e autores que considera essenciais na produção nacional de então, e termina argumentando que haveria "outras (obras), tão insignificantes que não poderiam aqui entrar sem de todo manchar as paginas que se vão ler" (ROMERO, 1878, p. 8).

Romero trabalha, portanto, com o jogo de cores já apresentado aqui, anteriormente. Com o determinismo do chiaroscuro - movimento na música do Classicismo europeu que alternava, subitamente, dinâmicas fortes e brandas, e cores de som escuras e claras - pretendia, quiçá inconscientemente, validar o discurso que antepunha cores desde o aspecto artístico e literário, até entre as próprias raças.

Quem viria se antepor, de forma contundente, ao cientificismo racial seria o antropólogo teuto-americano Franz Boas (1858-1942). Em A mente do ser humano primitivo, de 1911, rompeu, efetivamente, com os preconceitos arraigados na ciência da época de discriminar povos supostamente inferiores - ciência que comparava culturas como a europeia nórdica a de povos aborígenes, por exemplo, a quem alcunhariam de não-civilizados. No prefácio de 1938 à reedição dessa obra ele pontua que:

Não existe uma diferença fundamental nos modos de pensar do ser humano primitivo e civilizado. Uma estreita relação entre raça e personalidade nunca foi estabelecida. O conceito de tipo racial como é comumente utilizado até mesmo na literatura científica é enganador e requer uma redefinição, tanto lógica quanto biológica (BOAS, 2017, p. 6)

1 "L'infériorité technique est uniquement due à une infériorité de l'inteligence" (tradução minha). 
A concepção racista e, entretanto, altamente disseminada nos meios científicos da época, ecoaria por mais um século inteiro, menos na literatura oficial, e, conforme venho demonstrando, em abundância na Musicologia Brasileira. Com a releitura e revisão do Brasil sob a ótica de Gilberto Freyre, perpetuaram-se estigmas, ainda que tenha tido grande contribuiçáo ao estudo da cultura nacional. O maior estigma, da democracia racial, aparece perpetuado em sua obra, como na passagem seguinte, a respeito de negros incorporados ao seio de famílias brancas: "Muitas vezes concedeu-se a afilhados, crias, filhos naturais, o direito de tomarem de seus pais, padrinhos ou senhores brancos, nomes europeus e fidalgos de família: outra forma de confusão de plebeus com fidalgos, através da qual vem se democratizando a sociedade brasileira" (FREYRE, 1977, p. 399).

Essa sonhada e almejada democracia racial brasileira, de classe e de cultura, difundida por Freyre, obedece antes a uma visionária projeção de Nação do que uma efetiva mudança social. Parece ser da mesma ordem de devaneio dos portugueses, quando das Grandes Navegaçóes, que esperavam aqui encontrar a terra idílica onde aportariam, para sempre, e onde veriam o grande Paraíso ser materializado por meio de paisagens utópicas e seres fantásticos, como descreve Sérgio Buarque de Holanda em Visão do Paraíso (HOLANDA, 2000).

Diante dessa visível inadequação entre teoria e realidade, continuaram os brancos sendo brancos, dominadores, e os negros sendo subalternos. "A abolição traz a questão da inserção do negro vista por vários ângulos, pois no início do século XX - paralelamente à imagem que se constrói de uma sociedade em vias de modernização - e o negro não era mais que um elemento a ser diluído" (CARRIL, 2006, p. 47).

Nessa diluição afloraram os revisionismos históricos a respeito de figuras importantes do país. Entre os conhecidos negros que passaram a história como brancos, ou "mulatos", pardos, mestiços ou quase brancos, estão Antônio de Castro Alves, Joaquim Maria Machado de Assis e João da Cruz e Sousa, na Literatura, José Maurício Nunes Garcia e Antônio Carlos Gomes na música. Este compusera, em 1889 - por coincidência ano da Proclamação da República e um ano após a Abolição - a ópera Lo Schiavo (O escravo), em italiano e com libreto de Taunay, um de seus biógrafos, e teve que mudar o roteiro de última hora - o escravo negro, papel principal, teve de ser trocado por escravo indígena, devido ao preconceito da sociedade (MOURA, 2020).

Itala Gomez Vaz de Carvalho, em Vida de Carlos Gomes, de 1946, chega a considerar que a família do compositor tinha característica dos indígenas brasileiros, "muito diferente da côr moreno-amarela dos descendentes do negro africano" (CARVALHO, 1946, p. 217).

A preponderância do pensamento racista no Brasil da época levava os estudiosos a adotarem o vocabulário eugenista - muitos, como Freyre, inseriam palavras que corroboravam com o movimento do embranquecimento oriundo do arianismo alemão. Freyre, por exemplo, afirma que a inserção do negro de procedência provável da Guiné no ambiente doméstico do branco "mostra ter havido seleção eugênica e estética de pajens, mucamas e molecas para o serviço doméstico - as negras mais em contato com os brancos das casasgrandes; as mães dos mulatinhos criados e em casa - muitos deles futuros doutores, bacharéis e até padres" (FREYRE, 2016, p. 397). Percebe-se como Freyre adota o vocabulário hoje considerado racista - é comum encontrar a palavra "eugenia", que à época tinha conotação de "genes superiores", utilizada também em teoria cientificista e arianista. Lembrando que "eugenia", palavra do grego, significa "bem-nascido", e foi primeiro empregada como suposta ciência em 1883 por Francis Galton, segundo Fernando Rocha: "a eugenia significa o melhoramento genético. Os povos antigos costumavam matar as pessoas com graves 
deficiências físicas ou muito doentes. A história registra [...] que a ideologia de pureza racial sustentou as práticas de eugenia nazista" (ROCHA, 2017, p. 123).

Há de se reiterar que a teoria eugênica racial nazista culminou no Holocausto. Mais à frente Freyre pontua que no Brasil houve uma pressáo social para que o escravo fosse católico devoto e que ao longo dos anos são "capazes de transmitir às crianças brancas um catolicismo tão puro quanto o que estas receberiam das próprias mães” (FREYRE, 2016, p. 437).

Aqui percebe-se que compreendera, como homem esclarecido que era, a dicotomia que transcende os séculos, que traz arraigado o preconceito maniqueísta que opóe branquitude e negritude, supostamente característicos de Bem e Mal, respectivamente. No entanto, o próprio Mário de Andrade cairia em contradição, ao afirmar ser o pai de José Maurício "branco", em Música, doce Música (ANDRADE, 2006b, p. 121), sem ao menos averiguar as reais circunstâncias das origens de Apolinário Nunes Garcia - este também filho de uma negra escrava. Do mesmo modo, Andrade considera José Maurício como "moreno escuro" (ANDRADE, 2006b, p. 122) - o moreno se situaria entre o negro e o branco, e faria parte da desejada miscigenação da pátria branca perfeita.

Mário também teria aderido ao jogo de cores comum à Musicologia da época - contrastes de cores, principalmente adjetivados como "obscuros", "claros", "reluzentes". Em um artigo para a revista Ilustração Musical, de 1930, por exemplo, refere-se a José Maurício desta forma:

Já desde o meio do séc. XVIII porém, a música no Brasil tomava um surto muito grande especialmente sob o ponto-de-vista erudito com o famoso e liberal ensino de música aos negrinhos escravos no Sitio de Santa Cruz, então ainda em poder dos jesuitas. Os artistas saidos dêsse ensino sistematisado foram negros habilissimos, virtuoses mesmo; e da tradição deles, si não do proprio ensino porventura subzistente sem já a presença dos padres da Companhia, é que derivou o padre José Maurício, para coroar luminosamente o movimento. (ANDRADE, 1930, p. 78)

Parece contradizer-se, portanto, ao considerar, aqui, José Maurício "negro" - mesmo filho de um pai que considerava "branco"? O antagonismo cromático entre o meio em que crescera José Maurício - ensino musical aos "negrinhos escravos", aparentemente pejorativo - e a ascensão de José Maurício, "para coroar luminosamente o movimento" mostra que, mesmo entre os afrodescendentes, era difícil escapar ao estigma.

A tendência psicológica de antepor as cores negras e brancas maniqueisticamente fora resultado de uma autoanálise empreendida pelo psicanalista Carl Jung. O Núcleo de Estudos Interdisciplinares Afro-brasileiros da Universidade Estadual de Maringá realizou, em 2018, um estudo em que condensa e equipara pensamentos como o do filósofo alemão Georg Wilhelm Friedrich Hegel (1770-1831) - para quem o continente africano não faria parte da história do mundo - e coloca que Carl Jung costumava associar a Europa à civilização e à claridade com a obscuridade da África, um 'violento contraste entre o claro e o escuro' [...]" (ALVES et al., 2018, p. 112). Dessa forma, personagens históricos como o próprio Mário de Andrade viram-se, provavelmente inconscientemente, sustentando discursos maniqueístas de cor - e mesmo que metaforicamente, remetem a uma hierarquia cromática.

O questionamento ou afirmação "Mário de Andrade, um intelectual negro brasileiro", lembram figuras já históricas - pardas, mulatas ou "negras", ao sabor das circunstâncias ou conveniências - que viveram no final do século XVIII ou nasceram no XIX, cortejo de gente notável, tendo à frente, apon- 
tado como o caso mais emblemático para leitura racial, o nosso Machado de Assis, seguido de Paula Brito, Francisco Otaviano, Gonçalves Dias, em citação de apenas alguns personagens ligados às Letras (CAMARGO, 2018, p. 21).

$\mathrm{Na}$ visão de Camargo, haveria uma conotação eufemística nos termos "mulato" e "pardo", quando denominando pessoas de origem negra. Ao tentar "suavizar" a origem racial, muitos historiadores e literatos acabaram por redundar nesse eufemismo, o que vale quando Mário de Andrade utiliza a expressão "moreno escuro", por exemplo, para designar José Maurício (ANDRADE, 2006b, p. 122), ou quando Cleofe Person de Mattos designa as avós do Padre como "[...] duas criaturas de cor escura” (MATTOS, 1997, p. 17). Ao usar a palavra "criatura”, que parece, a um primeiro olhar, descaracterizá-la como humana - podendo significar, tanto homens como animais, ou mesmo "criaturas das trevas" ou "criaturas inanimadas", denota uma certa discriminação onde a cor escura dá a qualidade de "criatura" ao ser humano, de forma metonímica. Essa usança é concernente com o preconceito vocabular presente na caracterização de negros: "Na cor negra [...] está investida uma carga milenária de significados pejorativos [...]. O demônio, os espíritos maus, os entes humanos ou superhumanos, quando perversos, as criaturas e os bichos inferiores e malignos”, escreveu o sociólogo negro Alberto Guerreiro Ramos (1995, p. 241).

A tendência a separar mundos negros e brancos em mundos das trevas e de uma suposta pureza, respectivamente, rondou a própria retórica dos musicólogos afrodescendentes como Mário de Andrade. A respeito de um retrato seu pintado por Lasar Segall (1889-1957), pintor judeu russo então radicado em São Paulo, Mário escreve: "Como bom russo e bom judeu místico ele pegou o que havia de perverso em mim, de pervertido, de mau, de feiamente sensual. A parte do Diabo" (MATTOS, 1997, p. 174). Essa dualidade era comum quando referindo-se ao embate de negro e brancos. Encarnado como o Mal, o negro parecia representar tudo o que estava escondido no subconsciente, mesmo que em forma de anseios reprimidos. Conforme o relato de Mário, mesmo a sensualidade e a sexualidade eram relacionadas ao afrodescendente. As expressóes pejorativas que surgiram dessas associaçóes eram, ainda, consideradas comuns e plenamente aceitas na sociedade brasileira até o final do século XX. Petrônio Domingues explica como tornou-se constante o "amenizar" da raça, alcunhando o negro de "moreno", porque o substantivo-adjetivo havia incorporado a chaga da escravidão (DOMINGUES, 2008, p. 47).

Essa oposição cromática entre preto e branco não existe, porém, somente na cultura urbana ocidental. Entre os indígenas brasileiros da tribo Bororo, que habitam o estado do Mato Grosso, por exemplo, há o costume de se pintar de preto para nâo ser visto pelas almas do mal, que teriam sido responsáveis pelo falecimento de algum membro da tribo (LÉVI-STRAUSS, 1996, p. 248).

Ou seja, neste caso, a cor preta é entendida como algo que traz neutralidade ante o mal, um disfarce necessário à existência, sendo, portanto, alinhada junto às qualidades benignas. Na sociedade de classes, no entanto, a personificação do Mal estereotipada como o preto, o negro, traduzidas pelas expressóes coloquiais "humor negro", "a coisa está ficando preta", "o lado negro da força”, só reiteram o pejorativo simbolismo perpetrado, inconscientemente e mesmo a nível da consciência, no âmbito das relaçóes humanas modernas.

De acordo com Florestan Fernandes, foi por meio da organização dos movimentos negros que forjou-se uma "maior autonomia moral e intelectual da 'população de cor'. Por fim, logram até suplantar o temor pela identificação através do termo negro" (FERNANDES, 2008, p. 27). 
Fora Vicente Ferreira, do movimento social afro-brasileiro quem "introduziu [...] o termo negro para substituir o entáo vazio e usado homem de cor. Homem de cor também é o amarelo e o índio; acabou com essa baboseira de homem de cor, que não quer dizer nada" (MOREIRA; LEITE apud FERNANDES, 2008, p. 577). "À expressão "homens de côr" ou "população de côr" contrapunha-se o termo negro", coloca Elisa Nascimento (2003, p. 229).

Esse contraponto de cores remonta à escravidão e a separação entre raças, e a imposiçấo, a todo custo, do catolicismo cristão ao escravo negro. Uma fonte primária recolhida por Schlichthorst narra que um "médico zela por sua saúde corporal e um capelão, pela espiritual. Em regra, todos são batizados antes do embarque, marcando-se com um ferro quente uma pequenina cruz, no peito dos novos cristãos" (SCHLICHTHORST, 1943, p. 130).

Essa cruz fora marcada, de forma apenas psicológica, em José Maurício. Mas sua cruz seria visível apenas através de seus genótipos africanos, estereotipado como "homem de cor", conceito que o acompanharia na musicologia até os fins do século XX.

Em 1980, assim discorre Carlos Dantas a respeito do Padre: "Quem encarnava essa inesperada manifestação de talento era um genial homem de côr, nativo da Colônia, filho também de colonos e descendente pelo lado materno de uma crioula da Costa D'África" (DANTAS, 1980, p. 1).

O contraste entre o obscurecido Padre, pelo iluminado Marcos Portugal, mostra que desde a primeira publicação que se conhece sobre José Maurício - de Manuel Araújo de PORTO ALEGRE (1836), pouco se mudara em termos de perspectiva antropológica. E não deixa de empregar, em plena década de 1980, o jogo de cores táo presente na historiografia sobre ele: "Nos 14 anos que se seguiram até sua morte, José Maurício, ainda que obscurecido pela presença de Marcos Portugal, não deixou de provar a fecundidade de seu espírito criador, bem como manteve florescente o labor pedagógico" (DANTAS, 1980, p. 3).

Esse contraste se dava, além disso, não apenas no âmbito das cores em forma de metáforas - mas também no antagonismo entre classes, raças e estilos musicais. A música profana, por exemplo, tida como mundana e destituída de elementos elevados que pudessem ser apreciados dentro do templo, era associada aos negros - da mesma forma que o violáo, a modinha e todo canto que não trouxesse um texto de cunho religioso.

\section{A conceituação historiográfica mauriciana das teorias raciais sob o prisma da Etnomusicologia}

Comumente vimos, nesta tese, como a adjetivação levou muitos musicólogos a classificarem a música de José Maurício como "fina", "obscura", para dar dois exemplos antagônicos, variando pouco desde os primeiros escritos até o século XXI, até, por exemplo, o artigo de Medaglia (2017). Essas conotaçôes que críticos conferem à música por si só, por meio de qualidades subjetivas, devem ser olhadas sob o ponto de vista do contexto sociocultural de quem escreve - e há de se levar em conta que todos esses musicólogos, com exceção de Mário de Andrade, eram brancos, de classe média ou classe média alta ou puramente aristocratas, como Manuel de Porto Alegre e o Visconde de Taunay.

Muito embora o significado da música se materialize, em última análise,"nas notas" que os ouvidos humanos podem distinguir, pode haver diversas possíveis interpretaçóes estruturais de qualquer padrão sonoro, e um quase infinito 
número de respostas individuais à sua estrutura, dependendo do contexto cultural e estado emocional de seus ouvintes ${ }^{2}$ (BLACKING, 1973, p. 19-21).

Desta forma, muitas vezes os juízos de valor atribuídos por musicólogos a determinado repertório musical podem ter sido influenciados pelo ambiente cultural e sonoro dos quais eles provêm, além de sua própria história pessoal. O problema reside no fato de que poucos ou quase nenhum musicólogo brasileiro que versou sobre José Maurício tenha se debruçado, efetivamente, sobre sua produção musical como consequência direta de seu meio sociocultural, com desdobramentos nas estruturas sonoras que condizem com a contextualização política de sua época. A sua música, como a de muitos compositores, é tratada de maneira superficial - as notas e a harmonia sendo entendidas apenas sob a perspectiva estrutural, como se possuíssem vida própria independente. Esquece-se que a arte é proveniente, antes de tudo, do ser humano e das relaçóes sociais e culturais - a música só seria possível com a interação entre os homens, e suas relaçôes técnicas e de ordem teórica só são possíveis devido à existência humana e suas construçôes culturais.

Explicando sua metodologia, um dos pioneiros da Antropologia da Música, Alan Merriam, argumenta: "Aqui a ênfase foi colocada não tanto nos componentes estruturais do som musical, mas no papel que a música desempenha na cultura e na mais ampla organização social e cultural do homem"3 (MERRIAM, 1964, p. 4). Esse tipo de estudo antropológico do som almeja ressignificar os sentidos da própria música, indo além do espectro restrito da notação musical - notação que, na música erudita, adquire uma quase predominância sobre o conteúdo. Estando o acesso a essa notaçáo musical restrito apenas a uma minoria, inserida no contexto europeu ocidental e seus afluentes - elites do Novo Mundo e classe média pequeno-burguesa - a música torna-se ainda mais instrumento de poder, já que acaba sendo usufruída somente por quem compreende o complexo esquema de símbolos e códigos acadêmicos a ela inerentes - vide Marilena Chauí (CHAUÍ, 1993, p. 29).

A questão evidencia-se pelas ferramentas de poder outorgadas às elites por elas mesmas, para justificar e sedimentar a esmagadora supressão que exerce sobre as classes subalternas, segundo Michel Foucault em Microfísica do Poder (FOUCAULT apud CHAUÍ, 1993, p. 29). A mesma ferramenta de poder que, quase um século depois, Gilberto Freyre em uma passagem de sua internacionalmente reconhecida obra parece querer utilizar ao suavizar a submissão completa e agressiva a que o negro foi impelido pela escravidão:
Modinhas e cançóes, era ainda
a cantar - essas modinhas colon
grandes e das senzalas; do erotis
cangote cheiroso ou pelas prim
Elói Pontes recolheu uma tão expr
Meu branquinho feiticeiro,
Doce ioiô meu irmáo,
Adoro teu cativeiro,
Branquinho do coraçáo [...] (FREYRE, 2016, p. 424)

2 "Even though the meaning of music rests ultimately "in the notes" that human ears perceive, there can be several possible structural interpretations of any pattern of sound, and an almost infinite number of individual responses to its structure, depending on the cultural background and current emotional state of its listeners" (tradução minha).

3 "Here the emphasis was placed not so much upon the structural components of music sound as upon the part music plays in culture and its functions in the wider social and cultural organization of man" (tradução minha). 
Essa manifestação de aparente naturalidade na relação entre brancos e negras toma expressão musical idealizada na modinha. No entanto, não se sabe se essas "mulatinhas" a que Freyre se refere seriam realmente mestiças ou negras, devido à tendência de Freyre em embranquecer os negros de que trata, além de que o termo "mulato" tanto "podia designar uma mestiçagem étnica como referir-se a filhos ou descendentes de crioulos escravos, mesmo que de cor negra" (FARIA, 2004, p. 89).

A perspectiva seria de que, com o avanço e desenvolvimento dos movimentos sociais e a própria transformação da sociedade, se transmudasse também o modo de encarar as questóes raciais. Dessa maneira foram se redesenhando, aos poucos, as biografias de compositores como Beethoven - sempre associado com a música germânica, ícone maior do Romantismo, tinha ascendentes mouros. A quebra de paradigma que se dá a partir de então não é pequena. A associação de proeminência e protagonismo sempre com o caucasiano, encontrou em Beethoven o seu contraponto necessário e, espera-se, permanente. Não se trata de um revisionismo histórico, mas apenas recontar a história sob outra perspectiva: "Há um provérbio africano que diz que 'até que os leôes inventem as suas histórias, os caçadores serão sempre os heróis das narrativas de caça’." (SANTOS, 2018, p. 10) Com essa frase a historiadora negra Ynaê Lopes dos Santos introduz sua obra História da África e do Brasil afrodescendente.

Dominados pelo pensamento eurocêntrico por séculos, estivemos condicionados a atrelar os europeus ocidentais e os norte-americanos como exemplos idealizados de seres humanos que, obrigatoriamente, trariam arraigados características como beleza, virtude moral, superioridade intelectual, pureza e obstinação. "No pensamento eurocêntrico, o "ocidente" é o mundo "civilizado", "desenvolvido" e "superior", formado basicamente pela Europa Ocidental e pelos Estados Unidos (da América)" (SANTOS, 2018, p. 10).

No que concerne a essas qualidades acima mencionadas, já foi amplamente debatida nesta tese o conceito de "purificaçáo" e "germanizaçáo" da música brasileira colonial no tempo de José Maurício, tendência que, no entanto, permaneceram praticamente inalteradas até meados do século XX.

Todavia, mais importante do que avaliar os pendores clássicos de José Maurício é constatar que estas alegaçóes de influência e derivação não são neutras, porém revestem-se de densas conotaçóes valorativas, em termos estéticos e mesmo morais. Não estamos tratando apenas de uma escola com seus compositores, formas e estilos, mas de um Geist, de um etos germânico caracterizado por sua pureza, nobreza e austeridade. (HAZAN, 2008, p. 6)

A crescente germanização da música - que principia ainda no século XVIII, na música colonial - atinge seu apogeu na era da democracia racial, anos 1930 a 1950 . Nota-se que os musicólogos se constituíam antes de biógrafos a quem não cabia exercer qualquer estirpe de tom crítico. A presença constante, que acompanha a germanização, é a adjetivação minuciosa, detalhista, folhetinesca e que quase sempre esconde um indisfarçado juízo de valor. Para ilustrar, utilizo-me do exemplo a seguir, de Taunay:

Agora lá temos, no terreno da vasta exploração [...] dous maestros, educados na severa e conscienciosa escola allemã, a reconhecerem com emoção que José Maurício intimamente della deriva e é discipulo legitimo de Haydn e Mozart. Os velhos mestres allemães, são elles os verdadeiros e inabalaveis esteios da musica! (TAUNAY, 1930, p. 77) 
A valoração da música germânica como paradigma único para nortear toda arte do globo e a tendência à adjetivação, discurso de senso comum e análise unidimensional seriam, logo após os trabalhos de Merriam e Blacking citados acima, amplamente contestados. A ferramenta da Antropologia, a princípio destinada somente a pesquisas de cunho não-ocidentais e periféricos, logo demonstrou-se estar apta a transformar, também, a forma como se via a música de concerto ocidental (BLACKING, 1973).

"Aqui música não é entendida apenas a partir de seus elementos estéticos mas [...] como uma forma de comunicação que possui, semelhante a qualquer tipo de linguagem, seus próprios códigos. Música é manifestação de crenças, de identidades, é universal [...] em qualquer [...] sociedade". (OLIVEIRA PINTO, 2001, p. 223) Nesse artigo Tiago de Oliveira Pinto destaca como o simbolismo e a inserção sociocultural são fundamentais para se compreender a música sob o prisma atual, seja ela ocidental, não-ocidental, periférica, urbana, rural, folclórica, popular, erudita ou religiosa. Desta forma, os condicionantes valorativos de gosto pessoal não caberiam no processo analítico de qualquer tipo de obra musical - os adjetivos "severa", "conscienciosa", "legítimo", "verdadeiro" e "inabaláveis" da citação de Taunay acima não teriam espaço em uma pesquisa etnomusicológica contemporânea.

Uma análise justa de qualquer tipo de música deve considerar, segundo os autores mencionados, a organização sonora específica de sua cultura, seu contexto socioantropológico, as relaçôes que a música propicia e orienta entre os indivíduos de dada sociedade, sua função social, política e histórica. 


\section{Conclusóes}

Obedecendo esses parâmetros, podemos auferir que a música de José Maurício tinha funçóes sociais específicas: o culto, a cerimônia religiosa e a música da corte. Eventualmente, também teve funçóes políticas, como no caso da modinha "Beijo a mão que me condena”- de contestaçẫo particular pela sua subserviente condiçẫo humana. Mas no geral sua obra é voltada plenamente à religiâo católica cristâ, empregando o latim eclesiástico, $90 \%$ vocal, coral, com acompanhamento de órgáo ou orquestra, e cantores solistas. O seu evidente alinhamento com o Classicismo Vienense, entretanto, embora denote antes uma fiel e cega submissão aos padrões artísticos europeus vigentes, carrega a sua gana por sobrevivência em um tempo hostil ao homem negro - se é hostil hoje, imagine no tempo da escravatura. Sua adequação consciente ao estilo germânico pode ser historicamente compreendida, e, mesmo assim, é digno de nota seu empenho em fazer transparecer, mesmo nas missas mais sérias, laivos peculiares de brasilidade - como no exemplo de seu Tantum Ergo em Azevedo (1930).

Reminiscências modinheiras, traços sutis mas presentes de poesias urbanas de estilo trovadoresco trazem à tona um Padre José Maurício plural, preocupado, em suas limitações físicas e políticas, em soar brasileiro. 


\section{Referências}

ALVES, Amanda Palomo et al. (org.). Diálogos sobre diversidade, relaçôes raciais e desigualdade no Brasil. Maringá: Eduem, 2018.

ANDRADE, Mário de. Ensaio sobre a música brasileira. Belo Horizonte: Itatiaia, 2006a [1 $1^{\text {a }}$ ed. 1928].

. A modinha de José Mauricio. Ilustração Musical, n. 3, p. 78-81, 1930.

. Música, doce música. Belo Horizonte: Itatiaia, 2006b [1ª ed. 1933].

. Padre Jesuíno do Monte Carmelo. São Paulo: Martins, 1963.

AZEVEDO, Aluísio de. O mulato. Porto Alegre: L\&PM, 2013. [1ª ed. 1881]

AZEVEDO, Luiz Heitor Corrêa de. O espírito religioso na obra de José Maurício. Ilustração Musical, n. 3, p. 75-78, 1930.

. Música e músicos do Brasil: História - Crítica - Comentários. Rio de Janeiro: Casa do Estudante do Brasil, 1950.

AZEVEDO, Moreira de. Ensaios biographicos. Rio de Janeiro: F. A. de Almeida, 1861.

BLACKING, John. How musical is man? Washington: Washington Press, 1973.

BOAS, Franz. A mente do ser humano primitivo. Traduçáo de José Carlos Pereira. Petrópolis: Vozes, 2017 [1 $1^{\text {a }}$ ed. 1911-38].

CAMARGO, Oswaldo de. Negro drama: ao redor da cor duvidosa de Mário de Andrade. São Paulo: Ciclo Contínuo, 2018.

CARRIL, Lourdes. Quilombo, favela e periferia: a longa busca da cidadania. São Paulo: Annablume; Fapesp, 2006.

CARVALHO, Itala Gomes Vaz. Vida de Carlos Gomes. São Paulo: A Noite, 1946.

CHAUI, Marilena. Conformismo e resistência. 5a edição. São Paulo: Brasiliense, 1993 [1ª ed. 1986].

DESCAMPS, Paul. État social des peuples sauvages. Paris: Payot, 1930.

DOMINGUES, Petrônio. A nova Abolição. São Paulo: Selo Negro, 2008.

FARINACCIO, Pascoal. Serafim Ponte Grande e as dificuldades da crítica literária. São Paulo: Ateliê, 2001.

FERNANDES, Florestan. O negro no mundo dos brancos. São Paulo: Global, 2015. [1ª ed. 1949-52]

. A integração do negro na sociedade de classes. Volume II. São Paulo: Globo, 2008. [1ª ed. 1964]

FOUCAULT, Michel. The order of things: an archaeology of the human sciences. Londres 
e Nova Iorque: Routledge, 1970. [1 $1^{\text {a }}$ ed. 1966]

FREYRE, Gilberto. Casa-Grande e senzala. São Paulo: Global, 2016. [1ª ed. 1933]

. Sobrados e mucambos. Rio de Janeiro: José Olympio, 1977. [1ª ed. 1936]

GARCIA, José Maurício Nunes. Beijo a mão que me condena. Local desconhecido: Pierre FlfForge, 1837.

HAZAN, Marcelo Campos. José Maurício, Marcos Portugal e a Sonata de Haydn: Desconstruindo o Mito, Brasiliana, s/n, p. 1-11, 2008.

HOFBAUER, Andreas. Uma história de branqueamento ou o negro em questão. São Paulo: Unesp, 2006.

HOLANDA, Sérgio Buarque de. Raizes do Brasil. São Paulo: Companhia das Letras, 2016. [1 ${ }^{\mathrm{a}}$ ed. 1936]

. Visão do Paraíso. São Paulo: Brasiliense, 2000. [1ª ed. 1959]

JUNG, Carl Gustav. A vida simbólica: escritos diversos. Tradução de Edgar Orth. Petrópolis: Vozes, 2012 [1901-1961].

KRAUSE, Gustavo Bernardo. A reação do cético à violência: o caso Machado de Assis. In: Crônicas da antiga corte: literatura e memória em Machado de Assis. Belo Horizonte: UFMG, 2008.

LAKATOS, Eva Maria. Sociologia geral. São Paulo: Atlas, 1981.

LÉVI-STRAUSS, Claude. Tristes trópicos. Tradução de Rosa Freire D’Aguiar. São Paulo: Companhia das Letras, 1996 [1 $\left.1^{\text {a }} \mathrm{ed} .1955\right]$.

MATTOS, Cleofe Person de. José Maurício Nunes Garcia: Biografia. Rio de Janeiro: Biblioteca Nacional, 1997.

MEDAGLIA, Júlio. A contribuição do negro na cultura do Brasil, Revista Concerto, São Paulo, n. 242, p. 8, 2017.

MERRIAM, Alan P. The Antrhopology of Music. Michigan: Northwestern University, 1964.

MOURA, Clóvis. Sociologia do negro brasileiro. São Paulo: Perspectiva, 2020 [1988].

MUNANGA, Kabengele. Rediscutindo a mestiçagem no Brasil: identidade nacional versus identidade negra. 5a edição. Belo Horizonte: Autêntica, 2019 [2004].

NASCIMENTO, Abdias. O genocídio do negro brasileiro: Processo de um racismo mascarado. São Paulo: Perspectiva, 2016.

NASCIMENTO, Elisa Larkin. O sortilégio da cor: identidade, raça e gênero no Brasil. São Paulo: Selo Negro, 2003.

OLIVEIRA PINTO, Tiago de. Questóes de antropologia sonora. Revista de Antropologia, São Paulo, v. 44, n. 1, p. 221-86, 2001. 
PORTO ALEGRE, Manuel de Araújo. Ideias sobre música. Revista Nitheroy, Paris, 1(1), p.160- 183, 1836.

- Apontamentos sobre a vida e a obra do Padre José Maurício Nunes Garcia. Revista do Instituto Histórico e Geográfico Brasileiro, Rio de Janeiro, tomo XIX, p. 354-69, 1856.

RAMOS, Arthur. As culturas negras no Novo Mundo. São Paulo: Nacional, 1979. [1 a ed. 1935]

RAMOS, Alberto Guerreiro. Introdução crítica à sociologia brasileira. Rio de Janeiro: UFRJ, 1995. [1 $1^{\text {a }}$ ed. 1957]

RIBEIRO, Darcy. Os brasileiros: 1. Teoria do Brasil. Petrópolis: Vozes, 1978. . O povo brasileiro: a formação e o sentido do Brasil. São Paulo: Global, 2015 [1995].

ROCHA, Fernando Antônio Nogueira Galvão. Direito penal. São Paulo: Saraiva, 2017.

ROMERO, Sílvio. A philosophia no Brasil: ensaio crítico. Porto Alegre: Deutsche Zeitung, 1878.

SANTOS, Ynaê Lopes dos. História da África e do Brasil afrodescendente. Rio de Janeiro: FAPERJ, 2018.

SCHLICHTHORST, Carl. O Rio de Janeiro como é. 1824-1826. (Huma vez e nunca mais). Tradução: Emmy Dodt e Gustavo Barroso. Rio de Janeiro: Zélio Valverde, 1943 (1829).

SCHWARCZ, Lilia. O espetáculo das raças: cientistas, instituições e questão racial no Brasil 1870-1930. São Paulo: Companhia das Letras, 1993.

TAUNAY, Visconde de. Dous artistas maximos: José Mauricio e Carlos Gomes. São Paulo: Melhoramentos, 1930.

VACCARI, Pedro Razzante. Padre José Maurício Nunes Garcia e o mulatismo musical: embranquecimento histórico? Revista Música da USP, Sáo Paulo, v. 18, n. 1, p. 170-85, 2018. 